\title{
Method of Holt-Winters and Back Propagation FOR Prediction of Rice Production by Considering Rat Pest Attack
}

\author{
Hamid Wijaya \\ Master of Information System \\ Diponegoro University \\ Semarang, Indonesia
}

\author{
Vincencius Gunawan \\ Departement Of Physics \\ Diponegoro University \\ Semarang, Indonesia
}

\author{
Jatmiko Endro Suseno \\ Departement Of Physics \\ Diponegoro University \\ Semarang Indonesia
}

\begin{abstract}
Pest attack especially rodent can impact of reducing the production rice's crop and also triggering harvest failure. Therefore, forecasting system which is able to be used as monitoring tools for the production of rice is considered to be needed. This research is aim to provide solutions of prediction and area's mapping information of production using the HoltWinters and Backpropagation methods. Utilized data are planting area, rainfall, rat attack area, intensity of rat attack, harvested area and production of rice for 4 years since 2014 to 2017 which each year has 3 periods. The application of HoltWinters and Backpropagation methods resulted in the smallest MSE value of 0.02 with an accuracy of $99.8 \%$. Based on these accuracy values, Holt-Winters and Backpropagation method calculations give the appropriate result as it approaches the actual value.
\end{abstract}

\section{General Terms}

Prediction of rice production.

\section{Keywords}

Holt-Winters, Backpropagation, prediction, rice, rat.

\section{INTRODUCTION}

For gaining the optimal result from the production of agricultural sector, one of the efforts made by farmers is to prevent pest attack, which in our research case is a rat [1]. It is attacking the rice plants from the period of nursery till the harvest time. Furthermore, as another factor that can influence improvement of the rat's population in agricultural area especially in for rice crops is the irregular pattern of the planting phase. Therefore, existence of prediction report in order to alert rat's attacking is needed. Time series data from the past years can be utilized to gain the forecasting of production, hence, rat's attack is able to early controlled [2].

One of the time series prediction methods that can be used is Holt-Winters Method. Holt-Winters method is another term of Triple Exponential Smoothing which is used to model the data with the trend and seasonal patterns that appear at once in a time series data [3], then for decision making prediction results Backpropagation method is used. Backpropagation method is a systematic method for multiplayer training of artificial neural networks [4]. This method has a strong, objective mathematical base and this algorithm derives the form of equations and coefficient values in the formula by minimizing the sum of the squares of error through the developed model (training set) [5].

The advantages of the Holt-Winters method are the data that used is relatively small, the parameters used is fewer than the other similar method, the data types used do not contain seasonal, and easy elements in data management (no data transformation is required if the data used is not stationary and does not need to perform auto regression analysis) in making predictions. In addition, Holt-Winters method is capable of handling trend and seasonal data on a time series data [6]. Then the advantages of Backpropagation method is that it can process many variables and recognize the pattern and also it have the ability to learn from the data entered previously [7].

The previous work is done the research about the prediction of rice production in Odisha region of India. That research was using Autoregressive Integrated Moving Average (ARIMA) method. The data used in the study were historical data of planting area, productivity and rice production from 1950 to 2008 for predict the rice production for the next 3 years [8]. In that study, the prediction result was done using only 3 variables as input without considering the variable of pest attack such as rat pest attack which can affect rice production on prediction in the future.

Based on the previous work, in our case, we developed a prediction system utilizing the method of Holt-Winters and Backpropagation for predicting the rice production by considering rat pest attack as a form of pest control in order to increasing the rice production.

\section{RESEARCH METHODOLOGY}

\subsection{Holt-Winters}

The Holt-Winters method is another name for Triple Exponential Smoothing which is used to model data with the trend and seasonal patterns that appear at once in a time series data [3]. In our prediction we use the Holt-Winters Multiplicative method which includes 4 equations for the level $\left(L_{t}\right)$, the trend $\left(b_{t}\right)$, seasonal $\left(S_{t}\right)$ and prediction $\left(F_{t+m}\right)$ which is [9]:

$$
\begin{aligned}
& L_{t}=\alpha\left(Y_{t} / S_{t-s}\right)+(1-\alpha)\left(L_{t-1}+b_{t-1}\right) \\
& b t=\beta\left(L_{t}-L_{t-1}\right)+(1-\beta) b_{t-1} \\
& S_{t}=\gamma\left(Y_{t} / L_{t}\right)+(1-\gamma) S_{t-s} \\
& F_{t+m}=\left(L_{t}+b_{t} m\right) S_{t-s+m}
\end{aligned}
$$

In the above equation, $\alpha$ denotes the smoothing constant for the level, $\beta$ represents the smoothing constant for trend estimation, $\gamma$ represents the smoothing constant for the seasonal estimate, $Y_{t}$ represents the observed value or the 
actual value at the end of the period $t, m$ denotes the number of forecasts to be forward, $s$ denotes the length of the season cycle, $S_{t-s}$ declares the seasonal smoothing index $s$ of the past period [10]. From the equation above illustrates that the method used requires an initial initialization to minimize the estimated error measurement. So, to initialize the level $\left(L_{s}\right)$, the trend $\left(b_{s}\right)$ and seasonal $\left(S_{p}\right)$ then use:[11]

$$
\begin{aligned}
& L_{s}=\frac{Y_{1}+Y_{2}+Y_{s}}{s} \\
& b_{s}=\frac{Y_{s+1}-Y_{1}+Y_{s+2}-Y_{2}+\ldots Y_{2 s}-Y_{s}}{s^{2}} \\
& S_{p}=Y_{p} / L_{s}, \mathrm{p}=1,2, \ldots ., \mathrm{s}
\end{aligned}
$$

The Holt-Winters initialization process is valid for only one beginning of the seasonal period in the data. In addition, the magnitude of the coefficients $\alpha, \beta$, and $\gamma$ in the multiplicative Holt-Winters method has a range of from 0.1 to 0.9 [12]. The choice of usage of the weight of the smoothing coefficient $\alpha$, $\beta, \gamma$ can be done subjectively or by looking at the predictive error measurement level such as MAPE (Mean Absolute Percentage Error) generated varies on each $\alpha, \beta$ and $\gamma$ values. This can be done by trial and error. The use of MAPE can be seen in the following equations:[13]

$$
M A P E=\frac{\sum_{t=1}^{n}\left(\frac{Y_{t}-F_{t}}{Y_{t}}\right)}{n} \times 100 \% \quad t=1,2,3, \ldots n
$$

From equation above, $Y_{t}$ denotes the actual data in period $t, F_{t}$ represents the predicted value in period $t$, then $\mathrm{n}$ denotes the amount of data. From the above equation, $Y_{t}$ denotes the actual data in period $t, F_{t}$ represents the predicted value in period $\mathrm{t}$, then $\mathrm{n}$ denotes the amount of data.

\subsection{Backpropagation Algorithm}

Backpropagation method is a systematic method for multiplayer training of artificial neural networks [5]. The complete Backpropagation algorithm structure comprises [14]:

Step 0. Determine the learning rate $(\alpha)$. Determine the value of the desired error tolerance and the maximum set of an epoch (iteration) if the limit of the epoch used, Initialize weights and biases according to the weights generated in the training process.

Step 1. Each input $\left(X_{i}, i=1, \ldots, n\right)$ receives the input signal and transmits the input signal to all hidden layers. Where $X_{i}$ is the $i$-input unit.

Step 2. Every hidden layer (hidden unit) $\left(Z_{j}, j=1, \ldots, p\right)$ will send input signals with weight dan bias.

$$
z_{-} i n_{j}=v_{o j}+\sum_{i=1}^{n} x_{i} v_{i j}
$$

The activation function to calculate the output signal.

$$
z_{j}=v_{o j}+\sum_{i=1}^{n} x_{i} v_{i j}
$$

Then by using the activation function that has been determined obtained the output signal from the hidden unit and sends the signal to all units of the layer above it (the output layer). Where $z_{j}$ hidden unit to $j, v_{o j}$ the bias value for the hidden unit to- $j, v_{i j}$ the weight value of between the to- $i$ input unit with the to-j hidden unit.
Step 3. Each output unit $\left(Y_{k}, k=1, \ldots, m\right)$ sums the signals from the hidden unit by weight and bias.

$$
y_{-} i n_{k}=w_{o k}+\sum_{j}^{p} z_{j} w_{j k}
$$

The activation function to calculate the output signal, namely:

$$
y_{k}=w_{o k}+\sum_{j}^{p} z_{j} w_{j k}
$$

Then by using the activation function that has been determined obtained the output signal from the unit of output.

$$
y_{k}=f\left(y_{-} i n_{k}\right)
$$

For $w_{o k}$ is the bias value for the to- $k$ output unit, $w_{j k}$ the weight between the to- $j$ hidden unit and the to- $k$ output unit, $y_{k}$ unit output value to- $k$.

Step 4. Each unit of output yk receives tk terget pattern to calculate error $\left(\delta_{k}\right)$, that is.

$$
\delta_{k}=\left(t_{k}-y_{k}\right) \dot{f}\left(y_{-} n e t_{k}\right)=\left(t_{k}-y_{k}\right) y_{k}\left(1-y_{k}\right)
$$

Then calculate the value of weight correction which will be used to fix the weight value between hidden layer and ouput layer $\left(w_{j k}\right)$, that is.

$$
\delta w_{j k}=\alpha \delta_{k} z_{j}
$$

Calculate also the bias correction used to correct the bias value between the hidden layer and the output layer $\left(w_{o k}\right)$, as follows.

$$
\delta w_{o k}=\alpha \delta_{k}
$$

Where the value of th is the value of the $k$-target pattern.

Step 5. Each unit in the hidden layer $\left(z_{j}, j=1,2, \ldots, p\right)$ sums the input signals from the output layer, as follows.

$$
\delta \_i n_{j}=\sum_{k=1}^{m} \delta_{k} w j k
$$

Multiply this value by the activation function to calculate the error in the hidden layer $\left(\delta_{j}\right)$, as follows.

$$
\delta_{j}=\delta \_i n_{j} f\left(z \_i n_{j}\right)=\delta \_i n_{j} z_{j}\left(1-z_{j}\right)
$$

Then calculate the weight correction to correct the weight value between the input layer and the hidden layer $\left(v_{i j}\right)$, as follows.

$$
\delta v_{i j}=\alpha \delta_{j} x_{i}
$$

Then calculate the bias correction to improve the weight value between the input layer and the hidden layer $\left(v_{o j}\right)$, as follows.

$$
\delta v_{o j}=\alpha \delta_{j}
$$

Step 6. Each output unit $\left(y_{k}, k=1,2, \ldots, \mathrm{m}\right)$ improves the weights and biases, ie.

$w_{j k}($ new $)=w_{j k}($ old $)+\delta w_{j k},(k=1,2, \ldots, m ; j=0,1, \ldots p)$

Each hidden unit improves the weight and bias, namely:

$v_{i j}($ new $)=v_{i j}($ old $) \delta v_{i j}(j=1,2, \ldots, p ; \quad i=0,1, \ldots, n)$

Step 7. The stop condition test. As long as the stop condition is not met, do step 2 to 8 .

Next to evaluate the error rate then used MSE (Mean Square Error) through the equation [10]: 


$$
M S E=\frac{1}{N} \sum_{t=1}^{N}\left(Y_{t}-F_{t}\right)^{2} \quad t=1,2,3, \ldots n
$$

From the equation above, $Y_{t}$ denotes the actual data in period $t, F_{t}$ represents the predicted value in period $t$, then $N$ denotes the amount of data. From the above equation, $Y_{t}$ denotes the actual data in period $t, F_{t}$ represents the predicted value in period t, then $n$ denotes the amount of data.

\section{DESIGN OF RESEARCH}

\subsection{Material and Tools}

Materials and tools used to conduct this research are data of planting area, rainfall, rat attack area, intensity of rat attack, harvested area and production of rice for 4 years from 2014 until 2017. Within 1 year there are 3 periods of planting season so that total data of 12 periods are obtained from Balai Proteksi Tanaman Pangan dan Hortikultura Southeast Sulawesi. Then the tool used in this research is PHP and MySQL.

\subsection{Research Procedure}

The procedure of this study is shown in Figure 1 as follows:

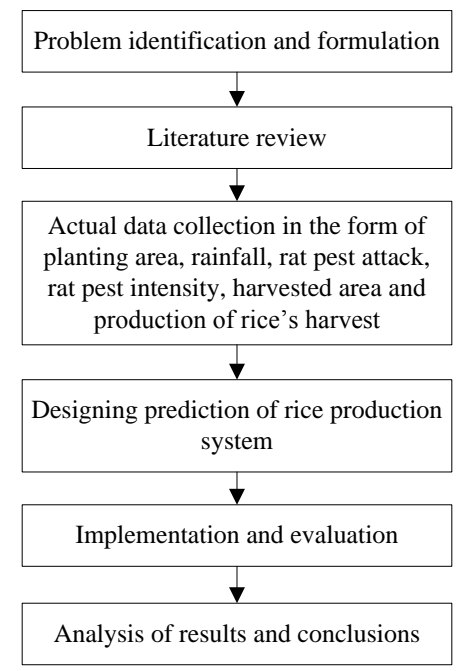

Fig. 1 Research Procedure

\subsection{Framework of Information System}

The Information system framework on this system is shown in Figure 2 as follows.

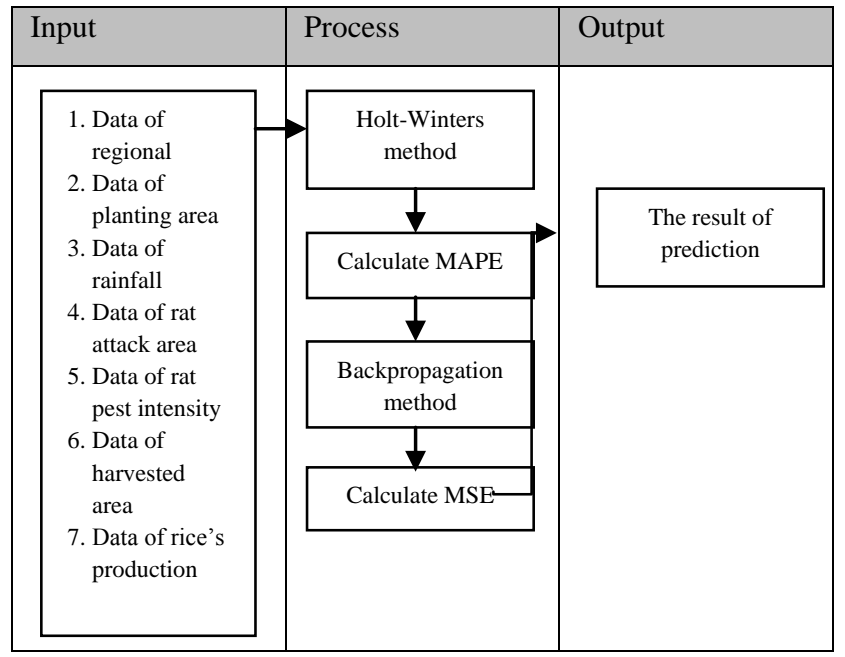

Fig. 2 Framework Information System

\section{RESULT}

In this research, we predict the production of rice yields by considering rat pest attack using the methods of Holt-Winters and Backpropagation. The first step at the Holt-Winters stage we determine the actual data that used for prediction. Actual data are planting area, rainfall, rat pest attack area and intensity of rat attack for 4 years from 2014 until 2017. In 1 year there are 3 periods of planting season so that the total data as much as 12 periods obtained from Balai Proteksi Tanaman Pangan dan Hortikultura Southeast Sulawesi as in table 1 below.

Table 1. Actual Data

\begin{tabular}{|l|l|l|l|l|l|l|}
\hline Period & $\begin{array}{l}\text { Planting } \\
\text { Area (Ha) }\end{array}$ & $\begin{array}{l}\text { Rainfall } \\
(\mathbf{m m})\end{array}$ & $\begin{array}{l}\text { Rat } \\
\text { Atack } \\
\text { Area }\end{array}$ & $\begin{array}{l}\text { Intensity } \\
\text { Rat At } \begin{array}{l}\text { Oftarvested } \\
\text { (\%) }\end{array}\end{array}$ & $\begin{array}{l}\text { Production } \\
\text { of Rice (Ton) }\end{array}$ \\
\hline $\begin{array}{l}\text { January- } \\
\text { April 2014 }\end{array}$ & 876 & 673.5 & 20 & 5.33 & 856 & 4108.8 \\
\hline $\begin{array}{l}\text { May-August } \\
\text { 2014 }\end{array}$ & 877 & 537.4 & 15 & 4.53 & 862 & 4137.6 \\
\hline $\begin{array}{l}\text { September- } \\
\text { December } \\
2014\end{array}$ & 880 & 159 & 25 & 3.33 & 855 & 4104 \\
\hline $\begin{array}{l}\text { January- } \\
\text { April 2015 }\end{array}$ & 879 & 1227 & 20 & 3.33 & 859 & 4123.2 \\
\hline $\begin{array}{l}\text { May-August } \\
2015\end{array}$ & 880 & 215 & 10 & 1.48 & 870 & 4176 \\
\hline $\begin{array}{l}\text { September- } \\
\text { December } \\
2015\end{array}$ & 877 & 269 & 20 & 5.26 & 857 & 4113.6 \\
\hline $\begin{array}{l}\text { January- } \\
\text { April 2016 }\end{array}$ & 880 & 895 & 15 & 2.79 & 865 & 4152 \\
\hline $\begin{array}{l}\text { May-August } \\
2016\end{array}$ & 876 & 622 & 11 & 1.48 & 865 & 4152 \\
\hline $\begin{array}{l}\text { September- } \\
\text { December } \\
2016\end{array}$ & 880 & 570 & 7 & 5.26 & 873 & 4190.4 \\
\hline $\begin{array}{l}\text { January- } \\
\text { April 2017 }\end{array}$ & 880 & 1007 & 11 & 0.37 & 869 & 4171.2 \\
\hline $\begin{array}{l}\text { May-August } \\
2017\end{array}$ & 879 & 659 & 7 & 5.26 & 872 & 4185.6 \\
\hline $\begin{array}{l}\text { September- } \\
\text { December } \\
2017\end{array}$ & 880 & 126 & 10 & 2.79 & 870 & 4176 \\
\hline
\end{tabular}

After obtaining the actual data, then the second step we determine the value of $\alpha, \beta$, and $\gamma$ parameters ranging from 0.1 - 0.9, then do initialization for the determination of the values of the level, trend and seasonal. After obtaining those values then we forecast future periods in trial and error to produce the best MAPE values ranging from $0 \%$ to $10 \%$ [15] as shown in table 2 .

Table 2. Result parameters and MAPE of the HoltWinters

\begin{tabular}{|l|l|l|l|l|}
\hline Variable & $\begin{array}{l}\text { Alpha } \\
(\boldsymbol{\alpha})\end{array}$ & Beta $(\boldsymbol{\beta})$ & $\begin{array}{l}\text { Gamma } \\
(\boldsymbol{\gamma})\end{array}$ & $\begin{array}{l}\text { MAPE } \\
(\boldsymbol{\%})\end{array}$ \\
\hline Planting area & 0.27992 & 0.07413 & 0.6285 & 0.00226 \\
\hline Rainfall & 0.54122 & 0.02365 & 0.22034 & 0.82487 \\
\hline Rat attack area & 0.11112 & 0.2226 & 0.42088 & 0.23675 \\
\hline $\begin{array}{l}\text { Intensity of rat } \\
\text { attack }\end{array}$ & 0.12085 & 0.67437 & 0.23994 & 1.17832 \\
\hline $\begin{array}{l}\text { Harvested area } \\
\text { Production of } \\
\text { rice }\end{array}$ & 0.08997 & 0.62053 & 0.43464 & 0.0045 \\
\hline
\end{tabular}


After obtaining the best $\alpha, \beta$ and $\gamma$ values as shown in table 2 then do the recalculation with Holt-Winters method to get predicted results from variable data of planting area, rainfall, rat attack area, intensity of rat attack, harvested area and production of rice as shown in table 3 below.

\section{Table 3. Predicted results with Holt-Winters}

\begin{tabular}{|l|l|l|l|l|l|l|}
\hline Period & $\begin{array}{l}\text { Planting } \\
\text { Area (Ha) }\end{array}$ & $\begin{array}{l}\text { Rainfall } \\
(\mathbf{m m})\end{array}$ & $\begin{array}{l}\text { Rat } \\
\text { Atack } \\
\text { Area } \\
\text { Ha) }\end{array}$ & $\begin{array}{l}\text { Intensity } \\
\text { of } \\
\text { Attack } \\
\text { (\%) }\end{array}$ & $\begin{array}{l}\text { Harvested } \\
\text { Area (Ha) }\end{array}$ & $\begin{array}{l}\text { Production } \\
\text { Rice (Ton) }\end{array}$ \\
\hline $\begin{array}{l}\text { January- } \\
\text { April 2015 }\end{array}$ & 876.3 & 729.4 & 18.9 & 4.9 & 857.4 & 4115.7 \\
\hline $\begin{array}{l}\text { May-August } \\
2015\end{array}$ & 878.5 & 846.6 & 13.4 & 3.5 & 865.1 & 4152.7 \\
\hline $\begin{array}{l}\text { September- } \\
\text { December } \\
2015\end{array}$ & 882.3 & 161.7 & 20.3 & 2 & 860.3 & 4130 \\
\hline $\begin{array}{l}\text { January- } \\
\text { April 2016 }\end{array}$ & 878.3 & 1038.6 & 15.3 & 3.2 & 863.3 & 4142.4 \\
\hline $\begin{array}{l}\text { May-August } \\
2016\end{array}$ & 879.6 & 676.8 & 9.3 & 2.2 & 872.5 & 4183.2 \\
\hline $\begin{array}{l}\text { September- } \\
\text { December } \\
2016\end{array}$ & 878.8 & 243.7 & 16 & 2 & 862.8 & 4147.5 \\
\hline $\begin{array}{l}\text { January- } \\
\text { April 2017 }\end{array}$ & 879.8 & 1829.6 & 10.9 & 2.6 & 869.2 & 4170.1 \\
\hline $\begin{array}{l}\text { May-August } \\
2017\end{array}$ & 878.2 & 967.5 & 6.8 & 1.5 & 874.8 & 4205.6 \\
\hline $\begin{array}{l}\text { September- } \\
\text { December } \\
2017\end{array}$ & 880.9 & 324.5 & 7.9 & 3.8 & 872.9 & 4182.7 \\
\hline $\begin{array}{l}\text { January- } \\
\text { April 2018 }\end{array}$ & 880.8 & 835.4 & 7.3 & 2.2 & 873.7 & 4193.5 \\
\hline $\begin{array}{l}\text { May-August } \\
2018\end{array}$ & 881.1 & 880.8 & 6 & 2.3 & 875.2 & 4201.1 \\
\hline $\begin{array}{l}\text { September- } \\
\text { December } \\
2018\end{array}$ & 881.4 & 926.1 & 4.7 & 2.4 & 876.8 & 4208.8 \\
\hline
\end{tabular}

In the Holt-Winters method, it produces predictions from 2015 to 2018 for 3 periods each from January - April, May August and September - December as shown in table 3 beforehand, then the data is processed by Backpropagation method.

Backpropagation method is required a training data and test data for determination of prediction of rice production by considering rat pest attack. Train data is used for data learning process, then test data used for testing data. The data we used are from 2015 to 2017 tested using data 2018 for 3 periods every year from January - April, May - August and September - December as shown in table 4 and table 5 below.

\section{Table 4. Data Training}

\begin{tabular}{|l|l|l|l|l|l|l|}
\hline Period & $\begin{array}{l}\text { Planting } \\
\text { Area (Ha) }\end{array}$ & $\begin{array}{l}\text { Rainfall } \\
(\mathbf{m m})\end{array}$ & $\begin{array}{l}\text { Rat Atack } \\
\text { Area } \\
\text { Ha) } \\
\text { of } \\
\text { Attack } \\
(\%)\end{array}$ & $\begin{array}{l}\text { Harvested } \\
\text { Area (Ha) }\end{array}$ & $\begin{array}{l}\text { Production of } \\
\text { Rice (Ton) }\end{array}$ \\
\hline $\begin{array}{l}\text { January- } \\
\text { April 2015 }\end{array}$ & 876.3 & 729.4 & 18.9 & 4.9 & 857.4 & 4115.7 \\
\hline $\begin{array}{l}\text { May-August } \\
\text { 2015 }\end{array}$ & 878.5 & 846.6 & 13.4 & 3.5 & 865.1 & 4152.7 \\
\hline $\begin{array}{l}\text { September- } \\
\text { December } \\
2015\end{array}$ & 882.3 & 161.7 & 20.3 & 2 & 860.3 & 4130 \\
\hline $\begin{array}{l}\text { January- } \\
\text { April 2016 }\end{array}$ & 878.3 & 1038.6 & 15.3 & 3.2 & 863.3 & 4142.4 \\
\hline May-August & 879.6 & 676.8 & 9.3 & 2.2 & 872.5 & 4183.2 \\
\hline
\end{tabular}

\begin{tabular}{|l|l|l|l|l|l|l|}
2016 & & & & & & \\
\hline $\begin{array}{l}\text { September- } \\
\text { December } \\
2016\end{array}$ & 878.8 & 243.7 & 16 & 2 & 862.8 & 4147.5 \\
\hline $\begin{array}{l}\text { January- } \\
\text { April 2017 }\end{array}$ & 879.8 & 1829.6 & 10.9 & 2.6 & 869.2 & 4170.1 \\
\hline $\begin{array}{l}\text { May-August } \\
2017\end{array}$ & 878.2 & 967.5 & 6.8 & 1.5 & 874.8 & 4205.6 \\
\hline $\begin{array}{l}\text { September- } \\
\text { December } \\
2017\end{array}$ & 880.9 & 324.5 & 7.9 & 3.8 & 872.9 & 4182.7 \\
\hline
\end{tabular}

Table 5. Data Testing

\begin{tabular}{|l|l|l|l|l|l|l|}
\hline Period & $\begin{array}{l}\text { Planting } \\
\text { Area (Ha) }\end{array}$ & $\begin{array}{l}\text { Rainfall } \\
(\mathbf{m m})\end{array}$ & $\begin{array}{l}\text { Rat } \\
\text { Atack } \\
\text { Area } \\
\text { Ha) }\end{array}$ & $\begin{array}{l}\text { Intensity Offarvested } \\
\text { Rat Attackarea (Ha) } \\
(\%)\end{array}$ & $\begin{array}{l}\text { Production of } \\
\text { Rice (Ton) }\end{array}$ \\
\hline $\begin{array}{l}\text { January- } \\
\text { April 2018 }\end{array}$ & 880.8 & 835.4 & 7.3 & 2.2 & 873.7 & 4193.5 \\
\hline $\begin{array}{l}\text { May-August } \\
2018\end{array}$ & 881.1 & 880.8 & 6 & 2.3 & 875.2 & 4201.1 \\
\hline $\begin{array}{l}\text { September- } \\
\text { December } \\
\text { 2018 }\end{array}$ & 881.4 & 926.1 & 4.7 & 2.4 & 876.8 & 4208.8 \\
\hline
\end{tabular}

In the process of training and testing the method of Backpropagation, 5 input criteria are used: planting area, rainfall, rat attack area, intensity of rat attack, harvested area and 1 output criterion which is production of rice. In addition to setting the value of parameters on the Backpropagation, a method is determined itself subjectively, such as the $\alpha$ value is 0.1 which is still in the range of values $0-1$, the value of tolerance error $=0.001$, iteration value $($ epoch $)=500$ and momentum $=0.1$. So as to produce predictions of rice production as shown in table 6 below.

Table 6. Data Prediction Result

\begin{tabular}{|l|l|}
\hline Period & $\begin{array}{l}\text { Prediction of Rice } \\
\text { Production Result }\end{array}$ \\
\hline January-April 2015 & 4125.4 \\
\hline May-August 2015 & 4157 \\
\hline September-December 2015 & 4140.7 \\
\hline January-April 2016 & 4152 \\
\hline May-August 2016 & 4176.6 \\
\hline September-December 2016 & 4148.6 \\
\hline January-April 2017 & 4175.6 \\
\hline May-August 2017 & 4180 \\
\hline September-December 2017 & 4176.3 \\
\hline January-April 2018 & 4179.3 \\
\hline May-August 2018 & 4180.6 \\
\hline September-December 2018 & 4181.6 \\
\hline
\end{tabular}

Based on the prediction results in table 6 we obtain the MSE value is 0.02 which it value is the smallest MSE from the calculation of iteration. After the prediction results are found, then compared it with the actual data. The graphic is shown in Figure 3. 


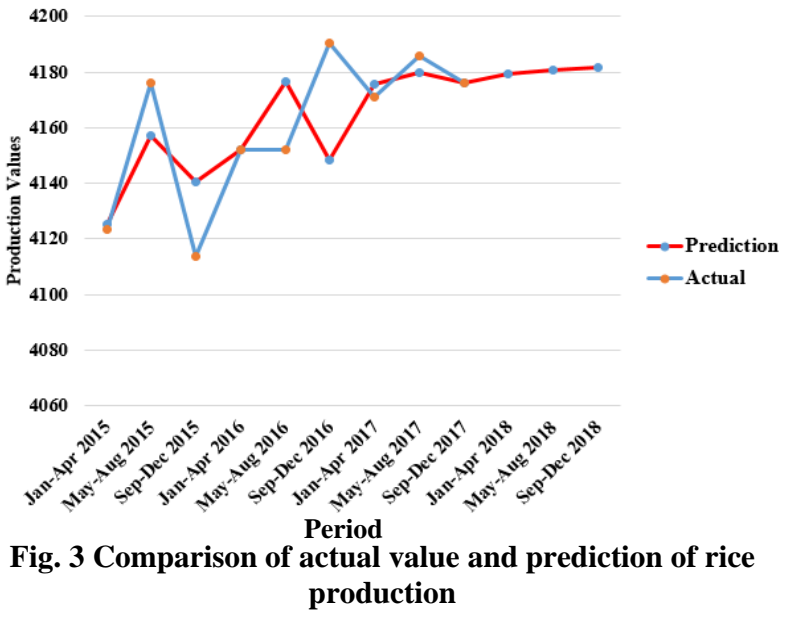

Based on Figure 3 above, it shows that the blue line represents the actual data line of production of rice, while the red line represents the line of prediction of rice production. Actual data start from 2014 to 2017 while the prediction data start from 2015 to 2018 for each 3 periods for 1 year (i.e. January April, May - August and September - December), then for actual data used tend to experience the trend rises from year to year so that the resulting predictions follow a rising trend that is similar to the actual data or an uptrend as well. In addition, according to the comparison between actual's data and prediction's data that obtain in this research, we found the result is $99.8 \%$. The result shows that level of accuracy is high.

\section{CONCLUSION}

From the research that has been done using Holt-Winters method and Backpropagation method to predict the production of rice plants by considering the pest attack of mice, it results MAPE value with very small percentage which is under $10 \%$. this result shows that this method is able to produce the highest accuracy in prediction. then for the Backpropagation method is resulting the smallest MSE value with the accuracy of almost perfect calculation of $99.8 \%$.

\section{REFERENCES}

[1] S. Kaboodvandpour and L. K. P. Leung, "Modelling density thresholds for managing mouse damage to maturing wheat," Crop Prot., vol. 42, pp. 134-140, 2012.

[2] Y. G. Lou, G. R. Zhang, W. Q. Zhang, Y. Hu, and J. Zhang, "Reprint of: Biological control of rice insect pests in China," Biol. Control, vol. 68, no. 1, pp. 103-116, 2014.

[3] A. Walters and Q. Cai, "Investigating the Use of Holt-Winters Time Series Model for Forecasting Population at the State and Sub-State Levels," $J$. Demogr. Work. Sect., vol. 2, pp. 7-8, 2008.

[4] A. Ganatra, Y. P. Kosta, G. Panchal, and C. Gajjar,
"Initial Classification Through Back Propagation In a Neural Network Following Optimization Through GA to Evaluate the Fitness of an Algorithm," Int. J. Comput. Sci. Inf. Technol., vol. 3, no. 1, pp. 98-116, 2011.

[5] J. Tarigan, Nadia, R. Diedan, and Y. Suryana, "Plate Recognition Using Backpropagation Neural Network and Genetic Algorithm," Procedia Comput. Sci., vol. 116 , pp. 365-372, 2017.

[6] P. Kalekar, "Time series forecasting using HoltWinters exponential smoothing," Kanwal Rekhi Sch. Inf. Technol., no. 04329008, pp. 1-13, 2004.

S. . Kosbatwar and S. . Pathan, "Pattern Association for Character Recognition by Back Propagation Algorithm Using Neural Network Approach," Int. Comput. Sci. Eng. Surv., vol. 3, no. 1, pp. 127-34, 2012.

[8] R. Tripathi et al., "Forecasting Rice Productivity and Production of Odisha , India , Using Autoregressive Integrated Moving Average Models," Adv. Agric., vol. 1, pp. 1-9, 2014.

[9] C. Chatfield and M. Yar, "Holt-Winters Forecasting: Some Practical Issues," Source J. R. Stat. Soc. Ser. D (The Stat. J. R. Stat. Soc. Ser. D Stat., vol. 37, no. 2, pp. 129-140, 1988 .

[10] L. Ferbar Tratar and E. Strmčnik, "The comparison of Holt-Winters method and Multiple regression method: A case study," Energy, vol. 109, pp. 266276, 2016.

[11] N. A. Elmunim, M. Abdullah, A. M. Hasbi, and S. A Bahari, "Comparison of GPS TEC variations with Holt-Winter method and IRI-2012 over Langkawi, Malaysia," Adv. Sp. Res., vol. 60, no. 2, pp. 276-285, 2017.

[12] G. Tirkeş, C. Güray, and N. Çelebi, "Demand forecasting: a comparison between the Holt-Winters, trend analysis and decomposition models," Teh. Vjesn. - Tech. Gaz., vol. 24, no. Supplement 2, pp. 503-509, 2017.

[13] U. Khair, H. Fahmi, S. Al Hakim, and R. Rahim, "Forecasting Error Calculation with Mean Absolute Deviation and Mean Absolute Percentage Error," J. Phys. Conf. Ser., vol. 930, no. 1, pp. 1-6, 2017.

[14] W. N. Networks, W. Now, H. Are, and N. Networks, Fundamental of Neural Network:: Architecture, Algorithm, and Application. New Jarsey: PrenticeHall, 1994.

[15] T. Baldigara, "Forecasting Tourism Demand in Croatia: A Comparison of Different Extrapolative Methods," J. Bus. Adm. Res., vol. 2, no. 1, pp. 84-92, 2013. 